Revista Iberoamericana, Vol. LXXVII, Núms. 236-237, Julio-Diciembre 2011, 703-716

\title{
FONDO NEGRO. LOS LUGONES: LEOPOLDO, POLO Y PIRI DE EDUARDO MUSLIP: REFLEJO DE LA DISCUSIÓN TEÓRICA ARGENTINA DE LOS AÑOS NOVENTA
}

\author{
POR \\ Ana Zapata-CALle \\ University of Missouri-Columbia
}

Eduardo Muslip nació en Buenos Aires en 1965. Estudió Letras en la Universidad de Buenos Aires y actualmente es docente universitario y crítico literario en Estados Unidos, aunque pasa largas temporadas en Argentina. Ha publicado las novelas Hojas de la noche (1996), Fondo Negro. Los Lugones: Leopoldo, Polo y Piri (1997) y los libros de cuentos Examen de residencia (2000) y Plaza Irlanda (2005). Participa también activamente en el mundo intelectual argentino como se ve por la publicación de sus cuentos en diversas antologías y en revistas literarias como $V$ de Vian, Pisar el césped y Mil Mamuts.

La novela Fondo Negro, al igual que Hojas de la noche, reproduce con el título mismo la idea de lo oscuro para constituirse como una obra de terror y de violencia en una situación que muestra el fondo oscuro de los brillantes héroes y hechos históricos. En la novela se presenta una realidad trágica impregnada por el horror de un pasado histórico que Muslip utiliza para comparar con el presente y mostrarlo como ficción anticipatoria de la caída del menemismo. El autor logra reflejar la profunda crisis de su tiempo al escribir una novela de metaficción historiográfica, retomando el pasado, al estilo del subgénero de la novela negra, recreándose en una realidad llena de crímenes, asesinos en serie, corrupción política, tortura, miedo, etc.

Fondo Negro es una obra que trata de completar, con un referente real, el clan de los Lugones, los vacíos de la historia a partir de una familia conocida en Argentina. Las cartas que Leopoldo Lugones enviaba a su amante, Emilia Santiago, se publicaron setenta años después de la muerte del poeta, a finales de los noventa. Estas cartas obligan a deconstruir la historia del ideólogo y del esposo fiel para contarla de otra manera, atendiendo a lo sórdido, a lo oscuro, al fondo negro de la vida de una familia marcada por la violencia y la tragedia. Leopoldo, Polo y Piri (padre, hijo y nieta) fueron muy conocidos en Argentina a través de la prensa: el padre como poeta e ideólogo, el hijo como torturador reconocido, y la nieta como escritora y montonera comprometida políticamente con la izquierda y, luego, por desaparecida. Pero Muslip no hace una 
novela histórica; no repite lo que ya se ha dicho oficialmente en los libros y en la prensa sobre estos personajes, sino que, recurriendo a subgéneros literarios como la novela negra, policial o de terror e incorporando textos tomados de revistas como La Nación, La montaña o Élite, nos ofrece una obra posmoderna donde los límites entre la realidad y la ficción se difuminan. Se incorporan también muchos diálogos que transmiten la idea de oralidad al texto y se toman o se inventan discursos oficiales, poemas, fragmentos de cartas, testimonios recreados de víctimas, o recuerdos de algún personaje. Todos estos textos marginales a la historia oficial se incorporan en cursiva en la novela como la otra cara de la historia, la intrahistoria de una familia y de un país. Con este doble discurso se ponen en cuestión los datos conocidos y se dota de un contexto conflictivo a los documentos públicos. La técnica narrativa de Muslip se adapta perfectamente a la definición del concepto de metaficción historiográfica propuesto por Linda Hutcheon en su artículo "Historiographic Metafiction: The Pastime of Past Time" (1989):

Historiographic metafictions appear to privilege two modes of narration, both of which problematize the entire notion of subjectivity: multiple points of view [...] or an overtly controlling narrator [...] In neither, however, do we find a subject confident of his/her ability to know the past with any certainty. This is not transcending of history, but a problematized inscribing of subjectivity into history [...] Postmodern intertextuality is a formal manifestation of both a desire to close the gap between past and present of the reader and a desire to rewrite the past in a new context. (117-18)

Muslip muestra un mundo de realidades complementarias, donde se juega con los conceptos del ser y el parecer, con el pasado y el presente, a partir de la narración de dos vidas paralelas, la de Leopoldo con su familia y su mundo social y la de Leopoldo con su joven amante Emilia Santiago. Ambos espacios confluyen en la conversación que, muchos años después de morir el poeta, mantienen en la ficción una Emilia anciana y Piri, la nieta del patriarca.

La historia de amor entre Leopoldo y Emilia comienza cuando ella, como estudiante, va a pedirle a la biblioteca que este dirigía un ejemplar agotado de Lunario sentimental (1909), donde se poetiza el amor a la esposa, para una de sus clases de literatura. Muslip juega con la idea de un amor 'agotado' del poeta hacia su esposa y el comienzo de una nueva producción de cartas inéditas dedicadas a su amante. El personaje de Emilia es clave para mostrar la vida del poeta a partir de varios puntos de vista:

Yo me veo en la clase de literatura, en la que hablan de un Leopoldo distante, fuerte, frió. Me veo desayunando en una mesa en cuyo cabezal mi padre, ignorante de todo, lee las notas de Leopoldo Lugones en La Nación. Me veo dejándote una carta en una casilla de correos, una más entre muchas [...] (72)

Revista Iberoamericana, Vol. LXXVII, Núms. 236-237, Julio-Diciembre 2011, 703-716 ISSN 0034-9631 (Impreso) 
Esta forma de recrear lo histórico en lo ficcional es lo que Ricardo Piglia llama "novela utópica”, con la que se complace en buscar lo verdadero a través de una ficción explícita que él mismo crea en obras como Respiración artificial (1980) o La ciudad Ausente (1992), donde se busca un mundo paralelo al aparente (Arán 124-25). Este paralelismo se hace muy claro en el texto de Muslip cuando se comparan los años noventa del siglo xix con los del siglo xx en comentarios como: "Me tiene harto la crisis de los noventa. Medio mundo se justifica de no tener nada por esa historia de la crisis del noventa” (61). También, los jóvenes de la Liga Patriótica que actuaron con actos vandálicos institucionalizados a principios de siglo $\mathrm{xx}$, al presentarlos como consumistas, violentos, pervertidos y rodeados de cosas lujosas, se podrían comparar con los mejores momentos del consumismo menemista.

Lo fantástico ayuda a narrar lo terrorífico y tanto Borges como Quiroga, como representantes del género del relato fantástico, están nombrados en la novela. Quiroga incluso aparece como personaje y con su presencia se crea la intertextualidad con el contenido de muerte, locura y desesperación de sus cuentos. La muerte está además presente en torno a este personaje porque participa en una expedición de limpieza o genocidio contra los indígenas que hay en una selva que están limpiando a "machetazos" en las orillas del río Yavebiri:

La vegetación, densa, húmeda, oscura. Iba siendo abierta a machetazos enérgicos, rápidos. Las gruesas botas de los exploradores pisaban el angosto sendero que se definía a medida que ellos avanzaban. La tierra roja se veía solamente en los rostros de los hombres [...] (Muslip 39)

Lo real y lo fantástico se mezclan al mismo nivel para crear el devenir histórico. En el relato de Muslip, lo fantástico es el recurso que se utiliza para narrar el horror. El tono gris y el negro ayudan a crear esas escenas donde las alucinaciones no permiten dilucidar los límites entre la realidad y lo ficticio:

Polo cumple su guardia en las puertas del cuartel. El cansancio, el sueño, el silencio, la inmovilidad, el tiempo eterno de la noche. Un hombre que camina a cien, doscientos metros, atravesando el campo, una forma aun más oscura que el fondo nocturno. El hombre va de un extremo del campamento hacia el otro, de izquierda a derecha. Polo intenta fijar la vista: el temor, casi el pánico, y el temblor que recorre su cuerpo, como atravesado por un relámpago: el hombre parece caminar sin tocar el suelo, las piernas se mueven con lentitud, pero avanzan aun más lentamente que si efectivamente estuviera tocando el piso.

El disparo, los gritos de Polo, la intervención de la guardia, la interacción de Polo en la enfermería. (54)

Revista Iberoamericana, Vol. LXXVII, Núms. 236-237, Julio-Diciembre 2011, 703-716 ISSN 0034-9631 (Impreso) 
Sobre el elemento fantasmagórico escribe Pampa Olga Arán en su artículo "Voces y fantasmas en la narrativa argentina" (2003) donde la crítica insiste en el concepto de la mimesis y en lo fantasmagórico de los relatos de ficción sobre la historia social de Argentina, ejemplificando sus argumentos con la obra de Piglia. La autora enfatiza que "lo fantástico tematiza el fantasma, aquello que está vivo y muerto simultáneamente, la apariencia de lo ausente” (125). Así, toda la novela de Muslip podría considerarse como un relato fantástico si analizamos su comienzo. En un cementerio, unos militares sacan el ataúd de Leopoldo Lugones de su tumba. En ese contexto dos mujeres se encuentran, Piri, la nieta del poeta, y Emilia, la que fue su amante. El ambiente es tétrico, y parece que nadie las ve: "El sol vertical del medio día, el calor agobiante del viernes dieciocho de febrero de 1978; las calles vacías alrededor del cementerio de la Recoleta, las confiterías despobladas de la calle Junin” (9).

Como en un cuento borgeano, el calor, el sol y la muerte del medio día nos llevan a un mundo de ultratumba donde las dos mujeres que hablan están muertas. Lo sabemos porque las cartas de amor que Leopoldo le escribió a Emilia y en las que se funda la reconstrucción de la historia no se publicaron hasta después de muerta Emilia Santiago, y porque al final del libro hay una nota que dice que Piri fue asesinada el 17 de febrero de 1978, es decir, un día antes del encuentro en el cementerio con Emilia. Así, serán dos personajes muertos los que se encuentren por primera vez y reconstruyan la historia como fantasmas. Piri podrá al fin entender su propio pasado gracias al encuentro con la otra vida de su abuelo. La metaficción historiográfica resulta verosímil dentro de una realidad fantástica que engaña al lector, ya que el encuentro entre las dos mujeres nunca se lleva a cabo en la vida de los referentes reales de los personajes, sino en periodo post mórtem imaginado.

Muslip se enfrenta al hecho de crear una ficción partiendo de un referente donde lo que prima son los asesinatos, los suicidios, las torturas, y discursos contradictorios desde muchos puntos de vista. En el pasado, el mismo Leopoldo Lugones y Jorge Luis Borges también crearon una ficción de la violencia argentina, conectándola con la creación de la identidad nacional. Lugones escribió la Historia de Sarmiento (1945), obra que se centra en el replanteamiento de lo que significa ser argentino. Por su parte, Borges escribió la introducción y notas de una edición del Facundo de Sarmiento en 1974. Así, si en el pasado la misma preocupación unió a los dos escritores, Muslip los identifica en Fondo negro unificándolos en un solo personaje bajo la imagen de un escritor y director de biblioteca en la oscuridad. Pero a diferencia de ambos, Muslip no escribe la historia de la misma manera, opta por otra forma de escribir, por una literatura al margen. Como Martín Kohan expone en "Mas acá del bien y del mal. La novela hoy" (2005), la originalidad y calidad literaria de los años ochenta y noventa está basada en un nuevo canon que se aparta de la literatura considerada "buena" donde se encuentran autores como Chejfec, Alan Pauls, Fogwill, o Aira, entre otros. Tras el

Revista Iberoamericana, Vol. LXXVII, Núms. 236-237, Julio-Diciembre 2011, 703-716 ISSN 0034-9631 (Impreso) 
Proceso de Reorganización Nacional argentino y, quizás, preguntándose lo mismo que Walter Benjamin y Günter Grass acerca de cómo narrar o cómo escribir después de Auschwitz, las soluciones textuales de Muslip se orientan hacia una literatura "mal escrita". Comparte con otros escritores la estética del lenguaje dañado, frases descriptivas sin verbos, constantes diálogos reflejo de la producción oral, tono gris o de blanco y negro en las descripciones de los espacios, capítulos cortos e inserción de fragmentos de textos de géneros menores como diarios, cartas de amor, o artículos periodísticos. Todo ello para combatir una forma de escribir literatura culta y elitista que estaba conectada con la violencia del poder.

Sobre la idea de mostrar el terror del pasado como reflejo del presente y de las técnicas utilizadas, Tulio Halperin Donghi escribe un análisis de la literatura de la metaficción historiográfica del terror en "El presente transforma el pasado: el impacto del reciente terror en la imagen de la historia argentina” (1987). Este análisis forma parte de la polémica producida en los años noventa para delimitar la "buena" o "mala" literatura. Estas discusiones están protagonizadas fundamentalmente por Andrea Pagni y Erna Von Der Walde:

Los términos en que se ha venido planteando este debate no dejan de ser problemáticos. Si de lo que estamos hablando es de democracia, ni la defensa de los medios, ni la defensa de la cultura de élite y de la escuela pueden sacarnos del atolladero. La insistencia sobre ese aspecto nos recuerda que la discusión cultural en la Argentina cobró importancia en el marco de la redemocratización, y que cuando se habla de cultura también se está hablando de política. (296)

La estética de la escritura dañada viene marcada por una nueva literatura caracterizada por el ready-made, la escritura como salga (escritos espontáneos, coloquiales, de expresión directa, reproducción del habla y pensamiento). Varios críticos han intentado crear un canon en torno a la reescritura del horror en los años noventa. Destacan entre ellos Carlos Gazzera en "Ficción y post sociedad. La memoria del horror en textos de la cultura argentina” (2006), Susana Romano Sued en “¿Los noventa?” (2003); y Miguel Dalmaroni en "La moral de la historia. Novelas argentinas sobre la dictadura (1995-2002)” (2003). Por otra parte, en el 2006, Sarlo recopila los textos escritos con esta estética que ella llama de "registro plano" como una crítica a la calidad literaria e intenta catalogar un nuevo canon en "Sujetos y tecnologías. La novela después de la historia" (4).

La narrativa de Muslip demuestra que siguiendo los rasgos de la literatura 'imperfecta' su obra tiene un gran valor literario y que la imperfección responde a un objetivo estético bien pensado. La narración se hace desde un narrador no omnisciente, que solo describe, de forma entrecortada, a veces sin verbos en sus frases, lo que ve. Es un narrador que no quiere introducirse en el mundo que narra, sino que lo presenta

\footnotetext{
Revista Iberoamericana, Vol. LXXVII, Núms. 236-237, Julio-Diciembre 2011, $703-716$
ISSN 0034-9631 (Impreso)
} 
como si estuviera en un lugar extradiegético, desde una butaca en el cine o frente a una imagen fotografiada cuyos rasgos imprecisos describe: “[f]ondo negro, rápidas y fugaces líneas horizontales de luz blanca. El sonido rítmico del tren. La ventanilla enmarcaba el paisaje nocturno que observaba Leopoldo Lugones, un joven de veinte, veintidós años, correctamente vestido y peinado" (13). El lector intuye un distanciamiento, quizás buscado para marcar una frontera con la moral del intelectual elitista del ayer que no quiere compartir o como representante de una sociedad argentina que ha visto todo sin querer o sin poder intervenir. La novela de Muslip, aunque cumple con los rasgos de la prosa dañada, como conjunto es un texto estéticamente muy logrado. Además, el collage de los documentos intercalados en la narración está artísticamente pensado para completar los vacíos de información que quedarían si no tuviéramos estos textos impresos estratégicamente en cursiva para mostrar lo marginal de la historia. Como dice Kohan al comparar los textos de Borges y Puig, no hay una oposición sino una complementación en la escritura. Escribir "mal” no es un descuido, sino una estética elaborada que se busca (11). Muslip participa de esta discusión sobre literatura 'buena' o ‘mala’ y la amplía un paso más al cuestionar la lectura de Borges. En Fondo negro, Piri reescribe a Borges desde la izquierda montonera, conectándolo con Rodolfo Walsh y el género policíaco (141).

Por otra parte, la narrativa de los noventa intenta ir más allá en la narrativización del horror. Se desprecia la versión maniqueísta de los hechos y hay un replanteamiento de responsabilidades y del origen de la violencia. Sarlo, en "Una alucinación dispersa en agonía” (1984), hace un acto de contrición sobre la responsabilidad de los intelectuales de izquierdas. De igual manera, en Fondo negro el personaje de Piri reflexiona sobre el papel de los intelectuales e insta a que se queden en el país y no se vayan. También reflexiona sobre su pasado y acerca de la relación con su abuelo, el ideólogo del Proceso de Reorganización Nacional, al que ella admira a pesar de ser montonera. Sin embargo, Piri desprecia profundamente a su padre, el torturador Polo, y siente una lucha dolorosa consigo misma por sus lazos de sangre. En la ficción, a pesar del desprecio, la comunicación entre el padre y la hija no se rompe hasta el día en que Polo decide suicidarse, cuando ésta se niega a hablarle. Esto hará a Piri sentirse culpable, no sólo por la muerte de su padre, sino por el suicidio de su hijo a raíz del suicidio de Polo. Se trata pues de mostrar una realidad argentina esquizofrénica donde todas las secciones políticas están conectadas, encadenadas, conviviendo en el mismo espacio sin que la división entre el "nosotros" y el "ellos" pueda ser delimitada al modelo maniqueo. En torno a la discusión de la delimitación de fronteras políticas, las novelas Villa de Luis Gusmán (1995) y El fin de la historia (1996) de Liliana Heker son claves para ver la indefinición de los límites. En el cine, frente a la forma de narrar en La historia oficial (1985) con su estética de "los dos demonios", un nuevo discurso donde todos tienen su propia responsabilidad en los hechos se presenta, como por ejemplo, en Garaje Olimpo

\footnotetext{
ISSN 2154-4794 (Electrónico)
ISSN 0034-9631 (Impreso)
} 
(1999) de Marco Bechis. Esto se enlaza con la discusión de Halperin, quien se muestra en desacuerdo con cómo se estaba viendo la historia a través del cine en "El presente transforma el pasado" (1987).

En Fondo negro a Leopoldo Lugones lo vemos por un lado como víctima y, por otro, como victimario, y sólo en el espacio compartido de una única familia con la que se muestran las posiciones políticas más dispares como una representación de las tensiones y violencia de todo el país. Esta familia, con cuatro generaciones muertas por suicidio o asesinato y desde posicionamientos políticos tan diferentes, constituye un referente real del caos político argentino que ha inspirado recientemente otra novela, Una tragedia argentina (2004), de Marta Merkin.

Adentrándonos ahora en la estructura del relato de la obra de Muslip, uno de los logros más interesantes del libro es la complejidad de su estructura. De hecho, se puede hablar de varias estructuras sobrepuestas que giran en torno a varios ejes: el viaje de Leopoldo Lugones, la desmitificación del poeta, la genealogía familiar, el torturador como centro del relato, la violencia y el cuerpo como mapa herido de un país.

\section{El ViaJe DE LEOPOLDo LugONES}

La escena del vagón de tren del principio de la novela, donde un Leopoldo Lugones joven y anarquista va a llegar a un Buenos Aires cambiante, es muy significativa en cuanto a que da al lector las claves para entender la dificultad y las tensiones de un espacio muy reducido donde personas de muy diferente posición política tienen que convivir. El espacio del vagón es una metonimia de Argentina como nación y el viaje refleja el origen, el desarrollo y la llegada al fascismo. La primera etapa recae en el tópico del viaje exótico que lleva a Leopoldo Lugones a un espacio habitado por prostitutas e inmigrantes. Emilia recuerda lo que Leopoldo le contaba:

En los primeros meses, no lo pasó tan bien... Vivió en hoteles con inmigrantes, prostitutas... Nunca me habló demasiado de eso, pero sin duda lo pasó realmente muy mal... Era una ciudad terriblemente hostil. Él era pobre, muy pobre, usted debe saberlo. Estuvo aquí un par de meses y corrió a Córdoba para casarse con... con su mujer. (24)

Su viaje a otra clase social acaba con su anarquismo y el personaje irá encaminándose progresivamente hacia un conservadurismo que le llevará al fascismo del que bebe y con el que se educa su hijo, el futuro torturador Polo Lugones. En la obra, la vida o el viaje de Leopoldo Lugones divide la narración en dos bloques: su ascenso hasta llegar al clímax y una decadencia más allá de su muerte. En la mitad del libro, colocado estratégicamente, se menciona el apoyo al golpe de Uriguru por parte de Lugones, y un capítulo de dos páginas impresas en cursiva ofrece al lector el discurso pronunciado por éste en Perú, como delegado argentino en los festejos del aniversario de la batalla de

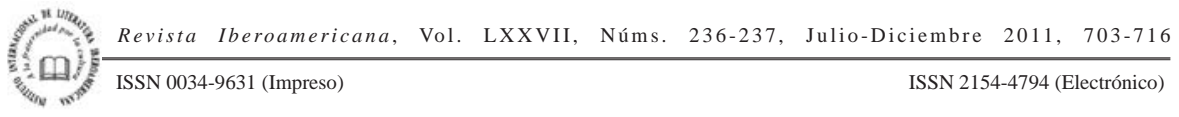


Ayacucho (87-88). Muslip incorpora este documento con un orden cronológico que no coincide con el real, ya que en el libro está situado entre el año 1929 y 1930, como una correlación al discurso de apoyo al golpe de Uriguru. Por cuestiones narrativas, Muslip sitúa el discurso entre estos años para mostrarlo como el clímax de su vida a partir del cual Leopoldo Lugones descenderá hacia el aislamiento y la hostilidad política en torno a lo social, y hacia el maltrato y decadencia familiar que sufrió a partir de la intromisión de su hijo Polo en su relación con Emilia Santiago. Una historia y una intrahistoria que el autor hace coincidir para dramatizar más una situación compleja que comienza con su caída tras la colaboración con Uriguru en el discurso de apoyo al golpe. Será una caída abrupta, el descenso a los infiernos que propiciará su muerte por suicidio y las consecuencias del desarrollo de su ideología en las generaciones posteriores. Leopoldo Lugones se presenta como el creador de un monstruo, su hijo Polo, en su viaje ideológico.

\section{LA DESMITIFICACIÓN}

El libro también se estructura circularmente. Se llevan a cabo dos conmemoraciones de la muerte de Leopoldo Lugones en distintos momentos históricos. La imagen del poeta célebre de Leopoldo Lugones es utilizada en las conmemoraciones para crear y mantener un mito, el apoyo y la imagen de una causa de manera elitista, ya que son muy pocos los que están en el cementerio para sacar el féretro que expondrán y muy pocos los invitados a las conmemoraciones. A través de la voz del margen de Emilia se ve cómo los que lo utilizan como mito son sus mayores enemigos, los que lo llevaron a la muerte, como son su hijo y los militares. El testimonio marginal de la amante cumple con la función de bajar al Lugones del mito para crear de él una versión más humana y compleja. Muslip hará lo mismo, lo sacará de su tumba al principio de la novela para reconstruir su historia, para desacralizarlo, para mostrar sus trapos sucios y dejar entrever la otra cara de la historia.

\section{LA GENEALOGÍA FAMILIAR Y EL TORTURADOR COMO CENTRO DEL RELATO}

Otra manera de analizar la estructura de la novela es a través de las genealogías. Aparecen varias generaciones de una misma familia y, por extensión, de las distintas etapas políticas y sociales de un país. Se ve a la familia Lugones como metonimia de toda una sociedad-nación fracasada, en una sucesión de generaciones perdidas. Otras novelas argentinas como Gaijin. La aventura de emigrar a la Argentina (2003) de Maximiliano Matayoshi, Una vez Argentina (2003) de Andrés Neuman, o Le digo me dice (2004) de Shila Vilker utilizan también la base de la familia y las genealogías para hablar de la realidad argentina en sus distintas fases. Muslip parte del patriarca, Leopoldo Lugones, pero estructura la obra en torno a su hijo, el torturador Polo Lugones. En el

\footnotetext{
ISSN 2154-4794 (Electrónico)
ISSN 0034-9631 (Impreso)
} 
texto, el padre se llena las manos de sangre en la escena del tren, mientras que Polo se llena las manos de 'mierda' (excrementos humanos) en sus torturas, y Piri sufrirá en su cuerpo todo el dolor de la tortura propiciado y planeado por las generaciones anteriores. Leopoldo ha creado con su ideología a un monstruo, pero no se da cuenta de ello hasta que es demasiado tarde. Así, cuando sus amigos le preguntan por su hijo, él responde: "Ese... esbirro. No me hable de ese esbirro" (109). Muchas víctimas de este esbirro pululan alrededor de la novela, incluso Leopoldo llegará a ser víctima de su propio hijo cuando éste se entrometa en su relación con Emilia.

Tomando el personaje de Polo como eje estructurador, se puede ver cómo la violencia es el centro de la novela. Se aprecia desde el principio una gradación de los actos violentos que llega a su máxima expresión en la escena donde el adolescente Polo, como integrante de la Liga Patriótica, y sus amigos matan a unas prostitutas. Después se producirá en el lector la naturalización de la violencia. El tema de la trivialidad del mal es tratado como reflexión por la filósofa, politóloga y teórica alemana Hannah Arendt en su libro Orígenes del totalitarismo (1951). En Fondo negro se asistirá a toda una galería insinuada, no expuesta explícitamente, de abusos, violaciones, torturas y asesinatos. Sus víctimas serán niños, mujeres, extranjeros, judíos, débiles en general o individuos físicamente "imperfectos" como Piri, que es coja, bajo el prisma del fascismo y ante un total conformismo de las autoridades. En esta realidad argentina, los monstruos no son los deformes, sino los que tienen bajo su mano el ejercicio del poder y de la ley. Por parte de la oligarquía elitista se ejerce una violencia institucionalizada que utiliza a los torturadores reconocidos para llevar a cabo una "limpieza" social como un programa estatal. Así, aun siendo Polo un torturador con credenciales y abusador de menores, llega a ser comisario de la policía. Piri exclama ante Emilia, perpleja ante este hecho:

-Es increíble que un hombre así haya conseguido los “trabajos” que consiguió [...]

-Esos trabajos -se anticipó Emilia - no los obtuvo tanto gracias a Leopoldo, sino por esos amigos que siempre tuvo... los muchachos de la liga Patriótica... (55-56)

Sobre la complicidad social ante la violencia y la tortura habla Klaus Schirmer en "Vergangenheitsbewältigung en un presente obturado. Modos de representación de la última dictadura militar en la reciente literatura argentina" (2003), donde escribe sobre una sociedad presente, paralizada como testigo. La consecuencia es la impunidad ante asesinatos, abusos, violaciones, torturas, masacres o represiones por una sociedad que no quiere juzgarse a sí misma, culpable de complicidad.

Asistimos en el relato al antes, al durante y al después de la acción del torturador. De dónde viene y adónde va en una visión global de la historia del siglo xx argentina desde 1895, con la llegada de Leopoldo Lugones a Buenos Aires, hasta cuando matan a su nieta montonera, Piri Lugones, en 1978, durante el Proceso de Reorganización Nacional. Como decíamos al comienzo, esta exposición y cuestionamiento de la historia

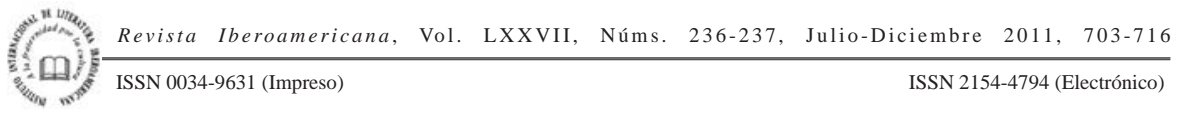


de una familia conocida argentina sirve para mostrar la violencia de la década del noventa del siglo xx conectada con la violencia del pasado como en un espejo, como una proyección de la caída del menemismo. Esta reescritura del horror conecta "aquel horror" con "este horror" de los noventa y la primer década del siglo veintiuno, como consecuencia de las políticas del menemismo, del neoliberalismo, de la globalización y del fin de las utopías sociales. Un ejemplo de este horror compartido lo encontramos al principio del libro de Martín Kohan, Dos veces junio (2002), un año después de la caída total del menenismo, donde un sargento le pregunta a un soldado a partir de qué edad se puede torturar a un niño, dejando perplejos a los lectores:

"Para usted, soldado”, dijo el sargento, “¿a partir de qué edad se puede comenzar a proceder con un niño?”. “Desconozco, mi sargento”, dije yo. "Ya sé que desconoce, soldado, pero yo le pregunto qué piensa”. Deje pasar un instante y le propuse: “A partir del momento en que la Patria lo requiera”. (25-6)

Ante la imposibilidad de expresar la violencia, se sugiere con un desplazamiento hacia lo metonímico con la técnica de la desfamiliarización. La memoria del horror en textos de la cultura argentina” (83-96), ofrece un canon de obras cuya característica principal es el énfasis en la imposibilidad de la expresión del horror, incluyendo novelas como Kamchatka (2003) de Marcelo Figueras, Aún (2003) de Mariano Dupont, y El grito (2004) de Florencia Abbate, entre otras.

\section{LA VIOLENCIA}

Si analizamos la violencia como elemento estructurador, tres son los momentos en los que se llega a sugerir el máximo grado de ella no sólo narrando los hechos violentos, sino mediante la sugerencia de unos hechos que los lectores conocen o mediante una estética que sugiere el terror. El primer momento de gran violencia ocurre cuando Leopoldo Lugones está en la selva para llevar a cabo la exploración del terreno suceso que llevará a la exterminación de los indígenas. El equipo construye una torre, como un observatorio muy débil, que temen se vaya a derrumbar. Esta escena refleja un estado argentino todavía en construcción. Leopoldo se sitúa en la parte más alta, como un ser superior, y observa a los indígenas desde arriba mientras ve el agua del arrollo pasar, como el símbolo del devenir histórico. Leopoldo se siente como un elegido, un jesuita o un conquistador (41), mientras que Quiroga abusa de una india lavandera, y el lector sabe que tanto ella como toda su tribu serán exterminados por la política del gobierno poco después. Sobre la violencia contra los indígenas se pueden nombrar otras obras como El entenado de Juan José Saer (1983) o Una excursión a los indios ranqueles (1870) de Lucio Mansilla.

ISSN 0034-9631 (Impreso) 
Otro momento cúspide de violencia es cuando la familia Lugones está en París con el general Julio Argentino Roca. Situados en una planta muy alta de un edificio estatal y considerándose como una élite europeizada totalmente distanciada del pueblo, observan a través de una ventana con prismáticos, como si estuvieran viendo un espectáculo teatral o la televisión, las matanzas de unos manifestantes proletarios. De la misma manera, la sociedad argentina de la década del noventa veía a través de los medios la violencia institucional, especialmente a través de la televisión. Leopoldo hace que el niño Polo presencie todo esto como parte de su educación. Para entender el grado de violencia en esta escena hay que recordar además que el general Roca fue el encargado del exterminio de las tribus indígenas en Argentina, del genocidio por la limpieza étnica.

El tercer momento de violencia es el de la escena donde están los adolescentes de la Liga Patriótica durante el tiempo de la Semana Trágica de 1919. Estos se encuentran en una planta muy alta de un edificio de Buenos Aires donde Polo y sus amigos adolescentes, tras haber vuelto de sus matanzas y apaleamientos dirigidos por los militares, contratan a dos prostitutas extranjeras para matarlas (61). Una de ellas muere a manos de Polo y a la otra la tiran todos por la ventana, estrellándola contra el pavimento. En esta tercera escena la violencia es atroz porque ataca a judíos, proletarios, extranjeros y mujeres.

La narración de estos tres momentos históricos lleva a una reflexión sobre el desarrollo del fascismo en Argentina y cómo esta ideología se practica generación tras generación contra los más desfavorecidos socialmente. Cronológicamente, la violencia se va haciendo gradualmente más explícita, revelando un crecimiento constante de la violencia, encaminada hacia el presente y el futuro del narrador. Además, si en un primer momento se ataca a los indígenas, después es a los revolucionarios europeos y, tras ellos, a las masas urbanas argentinas más pobres y desprotegidas. La violencia se desplaza del campo a la ciudad, y siempre es la élite urbana quien la profesa, invirtiendo la idea dicotómica de civilización y barbarie decimonónica, cuyo replanteamiento ya había sido expresado por Roberto Arlt en sus obras vanguardistas. Por otra parte, metafóricamente en los tres casos existe la idea de la caída abrupta desde la altura. Esta isotopía podría verse como la imagen anticipatoria de la caída del menemismo del 2001. También es común la obsesión por la limpieza, material y étnica, como principio del fascismo. Con el tema del antisemitismo y el fascismo se pueden relacionar otras novelas del ciclo judío como son Los gauchos judíos (1974) de Alberto Gerchunoff; Una vez Argentina (2003) de Andrés Neuman; Le digo me dice (2004) de Shila Vilker; o Auschwitz (2004) de Gustavo Nielsen, entre otras. En cuanto a la xenofobia o a la violencia a la que los extranjeros son sometidos también se han escrito otras novelas como la de Maximiliano Matayoshi, La aventura de emigrar a la Argentina (2003).

\footnotetext{
Revista Iberoamericana, Vol. LXXVII, Núms. 236-237, Julio-Diciembre 2011, $703-716$
ISSN 2154-4794 (Electrónico) 


\section{EL CUERPO}

El cuerpo recibe la violencia de los torturadores. Carmen Perilli escribe en "Cuerpo y letra en la novela argentina (1982-1994)" sobre el cuerpo de la mujer como objeto sexual y de tortura; en Fondo negro se habla de violaciones, abusos y torturas que matan lentamente a la mujer. Violar es una de las técnicas de tortura de Vaccaro, mientras que Polo no viola a las mujeres porque no se siente atraído por ellas, sin embargo, las maltrata como hace con su mujer y con su hija Piri, y las mata, como hace premeditadamente con la prostituta: "Un cuarto en un lupanar. El cuerpo retraído de Polo, la prostituta en la cama, el grito de la mujer, la sangre que se desliza hacia el vientre, hacia las sábanas, y se absorbe en la cama” (63). El cuerpo de la mujer se puede ver como reflejo de una Argentina a la que se está desangrando poco a poco, lentamente, especialmente a la izquierda política, la mano que Piri deja de sentir. El final de la novela acaba con un reflejo de este dolor intenso de Argentina descrito a través de las sensaciones de Piri: "La respiración le dolía; le dolía la espalda, le dolía aún más la cadera, le dolían las

piernas. No le dolía la mano izquierda: no parecía pertenecer a su cuerpo” (179). Por otra parte, el fascismo, asociado al cuerpo masculino, es deseado por Polo:

[I]nmóvil en el sillón, la mirada de Polo observaba los cuerpos de cada uno de sus amigos. Los rostros, los cuerpos de cada uno de los otros jóvenes de la habitación parecían separarse del lugar y de sus movimientos; veía cada uno delante de un fondo negro [...] (63-64)

El tema del cuerpo nos lleva al tema del país como matadero. La literatura de los noventa vuelve sus ojos a la de los años setenta. Se alude a la escritura de Osvaldo Lamborghini como literatura anticipatoria de la violencia del Proceso de Reorganización Nacional. Su versión de El matadero titulada El niño proletario (1973) invoca a una Argentina en manos de un tirano, pero con una diferencia con respecto al original: "Si Echeverría fundó la literatura argentina con la metáfora de la violencia política de la ‘carne’ sobre el 'espíritu', Lamborghini escribía [...] la violencia del ‘espíritu’ sobre la 'carne”” (Gazzera 84). No olvidemos que Rodolfo Walsh, escritor incluido en la novela como personaje y con quien Piri tiene una relación amorosa, ya había escrito un Matadero en 1967 donde la violencia pasa del campo a la ciudad (Link 63). También Borges había hecho su propia adaptación en 1942 con su Poema Conjetural y este mismo movimiento se produce en Fondo negro, como hemos visto.

Los temas en torno a los cuales se estructura el texto, tales como el viaje de Leopoldo Lugones, la desmitificación del poeta, la genealogía familiar, el torturador como centro del relato, la violencia y el cuerpo como receptor del dolor, plasman una realidad insostenible de la Argentina contemporánea para el autor, así como una metáfora anticipatoria del desastre económico liberal del menemismo. Muslip, en su novela,

Revista Iberoamericana, Vol. LXXVII, Núms. 236-237, Julio-Diciembre 2011, 703-716 ISSN 0034-9631 (Impreso) 
como Carolina Grenoville en "Límites y consecuencias políticas de la representación" (2006) apuesta por el compromiso del intelectual en la literatura y por la recuperación del discurso político del pasado, en los noventa, contra la indiferencia moral de la élite intelectual conservadora. Si bien el libro acaba con el proceso de muerte lenta infringida a Piri a partir de la tortura, no hay una lectura pesimista. El hecho de que Piri vea un triángulo de luz en el lecho de su muerte motiva a la esperanza, a la continuación de la lucha. Para Muslip como para Genoville, la muerte del cuerpo no es la muerte de la causa. Por eso, los muertos, Piri y Emilia, viven en su obra con más presencia que los vivos, para recrear un discurso histórico y comprometido que cuestiona las políticas del poder.

\section{OBRAS CITADAS}

Arán, Pampa Olga. “Voces y fantasmas en la narrativa argentina”. Umbrales y catastrofes: literatura argentina de los 90. Susana Romano Sued y Pampa Olga Arán, eds. Córdoba: Epoké, 2003. 124-64.

Arendt, Hannah. Orígenes del totalitarismo. 1951. Madrid: Alianza, 2006.

Dalmaroni, Miguel. "La moral de la historia. Novelas argentinas sobre la dictadura (1995-2002)”. La palabra justa. Literatura crítica y memoria en la Argentina, 1960-2002. Santiago de Chile: Melusina, 2004. 155-174. También disponible en Hispamérica: Revista de Literatura 96 (2003): 29-48.

Garage Olimpo. Dir. Marco Bechis. Escrito por Marco Bechir y Lara Fremer. Urban Films, 1999.

Gazzera, Carlos. "Ficción y postsociedad. La memoria del horror en textos de la cultura argentina”. Ficciones del horror. Literatura y dictadura. Carlos Gazzera y Carlos Surgí, eds. Córdoba: Recovecos, 2006. 83-86.

Grass, Günter. “Cómo escribir después deAuschwitz”. Página 30 6/1(enero 1991):11-18.

Grenoville, Carolina. "Límites y consecuencias políticas de la representación. La narrativa argentina contemporánea frente a la experiencia del terror de Estado". $V I^{\circ}$ Congreso Internacional Orbis Tertius de Teoría y Crítica Literaria. Universidad Nacional de la Plata. La Plata. 10-12 mayo 2006. Ponencia.

Halperin Donghi, Tulio. "El presente transforma el pasado: el impacto del reciente terror en la imagen de la historia argentina”. The Historical Novel in Latin América. Daniel Balderston, ed. Baltimore: Hispanoamérica, 1987. 71-95.

Hutcheon, Linda. "Historiographic Metafiction: The Pastime of Past Time." A Poetics of Postmodernism. Nueva York: Routledge, 1989. 105-123.

Kohan, Martín. Dos veces junio. Buenos Aires: Sudamericana/Delbolsillo, 2008.

"Más acá del bien y del mal. La novela hoy". Punto de Vista 83 (2005): 7-12.

Link, Daniel. "Ein Bericht für eine Akademie: Violencia, escritura y representación (1973-1993 en el Río de la Plata)”. Culturas del Río de la Plata (1973-1995):

\begin{tabular}{l} 
Revista Iberoamericana, Vol. LXXVII, Núms. 236-237, Julio-Diciembre 2011, $703-716$ \\
\hline ISSN 0034-9631 (Impreso)
\end{tabular} 
transgresión e intercambio. Roland Spiller, coord. Frankfurt am Main: Vervuert Verlag, 1995. 51-68.

Muslip, Eduardo. Fondo Negro. Los Lugones: Leopoldo, Polo y Piri. Buenos Aires: Solaris, 1997.

Pagni, Andrea y Erna von der Walde. “Qué intelectuales en tiempos posmodernos o de 'cómo ser radical sin ser fundamentalista'. Aportes para una discusión con Beatriz Sarlo”. Culturas del Río de la Plata (1973-1995): transgresión e intercambio. Roland Spiller, coord. Frankfurt am Main: Vervuert Verlag, 1995. 287-312.

Perilli, Carmen. "Cuerpo y Letra en la novela Argentina (1982-1994)”. Culturas del Río de la Plata (1973-1995): transgresión e intercambio. Roland Spiller, coord. Frankfurt am Main: Vervuert Verlag, 1995. 121-30.

Romano Sued, Susana.“¿Los noventa?” Umbrales y catástrofes: literatura argentina de los 90. Susana Romano Sued y Pampa Olga Arán, eds. Córdoba: Epoké, 2003. 9-21.

Sarlo, Beatriz. "Una alucinación dispersa en agonía”. Punto de vista 21 (1984): 1-4. "Sujetos y tecnologías. La novela después de la historia". Punto de Vista 86 (2006): 1-6.

Schirmer, Klaus. "Vergangenheitsbewältigung en un presente obturado. Modos de representación de la última dictadura militar en la reciente literatura argentina”. Umbrales y catastrofes: literatura argentina de los 90. Susana Romano Sued y Pampa Olga Arán, eds. Córdoba: Epoké, 2003. 131-50.

ISSN 0034-9631 (Impreso) 